\title{
An Ode to a Nephron
}

Like thoughts in one's life, some superficial and some deep.

Some cortical, whilst other, down close to medulla they seep. ${ }^{1}$

All along our life, we learn and absorb, with efforts active and passive. ${ }^{2}$

Concentrate and dilute our endeavors, by proportions little and massive.

Like experiences of life, which we filter and retain.

So does the nephron, absorbs the electrolytes' rain. ${ }^{3}$

Each moment. Bowman's embrace challenges, the challenges brought by afferents.

It must filter some things out, and return the rest through efferents.

* The author's views.

Signifies cortical and juxtamedullary nephrons. While some people are superficial and restrict their thought process to factual aspects of life, some others have an emotional depth and abstractness to their existence. Just a matter of individual constitution.

2 Connotes the active and passive processes involved in absorption. For some things in life, we actively try; while for others, we passively accept.

3 Reflects various encounters in one's life. Afferents bring blood to the Bowman's capsule and filtration occurs here. Proteins and other required constituents are selectively retained and the ultrafiltrate goes distally.
The more I think of it, the more I believe it to be true. If any cell in the body most closely resembles one's life, it is a nephron.*

Like a smart trader, its proximal barters, ${ }^{4}$ hydrogen for ions, in silence and placid.

Exchanges the $H$, for salt and sugar, ascorbic, amino and uric acid. ${ }^{4}$

The life must move on, and loop its course, to descend and then to ascend.

We must advance and yearn, to overcome and transcend. ${ }^{5}$

In our youth, we stand firm and resolute. ${ }^{6}$

We age and experience, distal years of our lives convolute. ${ }^{7}$

To solve the mysteries of life, we think, feel and act.

Sensing the ups and downs of salt, offers macula densa its impact. ${ }^{8}$

\begin{tabular}{ll}
\hline KARGER & ( 2004 S. Karger AG, Basel \\
Fax +416130612 34 & 0250-8095/04/0241-0162\$21.00/0 \\
E-Mail karger@karger.ch & Accessible online at: \\
www.karger.com & www.karger.com/ajn
\end{tabular}

4 Proximal convoluted tubules and absorption that takes place in this segment of nephron. In life as well, one barters several attitudes, to attain a stage most suitable for survival.

5 Loop of Henle its descending and ascending limbs. Compared to adolescence and later the youth of life.

6 Resolute reflects the nephron's attitude in the ascending limb (compared to one's strong youthful years), and conveys this part's impermeability to water. 7 Distal convoluted tubule.

8 Macula densa and its role as renal sensor element to sense sodium concentration and offer feedback effect on the Bowman's capsule. Comments on nephron's ability to sense and feel.
Deepak Asudani, MD

1918, First Avenue, Mail Box \# 245

New York, NY 10029 (USA)

Tel. +1 6466443627

E-Mail asudani@aol.com 
Like our thoughts, flow the ions, in and out and in and out.

To retain what we need, and part with one's we can do without.

The art of improvement and discipline, through counter current and autoregulation.

Akin to self-control and evolution, through practice, prayer and meditation.

Like our life, where experiences abound, we improve, develop and rectify.

A little nephron sits there, to secrete, absorb and purify.

As life wanders and winds, the nephron meanders its way. ${ }^{9}$

To part with toxins and miseries, all through the night and day.
There is only so much it can handle, only so much agony and so much pain.

Struggles, yearns and lives a purposeful life, before it gets slain.

The juggling bubbles of salts and water, through capsule and tubules.

Like the puzzling frenzies of a human life, through breaches and rules.

Oh! What an institution, interplay of renin, $A D H$ and aldosterone. ${ }^{10}$

Oh! How much like one's life, what a masterpiece is a Nephron.

Deepak Asudani, MD

New York Medical College/MHC
9 Comments on tortuous course a nephron takes. Compares to various stages and circumstances one comes across in life.

10 Analogy to various factors determining renal function, much like the factors altering one's life course.
The superscripts given at the end of stanzas explain the poet's analogy. Analogy is only briefly explained here. 